\title{
ERRATA
}

\section{VOLUME 27}

Page 369, line 11. For "Aмemya», read "AмemiYA».

\section{VOLUME 28}

Page 333, column 1, line 18. For "AмEMYA», read "AMEMIYA》.

Page 342 , column 2 , line 20 from below. For $« 383 »$, read « $283 »$.

\section{VOLUME 30}

Page 429, column 1, line 12. For «of», read «in».

\section{VOLUME 34}

Page 108, line 24 from below. For "proof», read "truth».

Page 743, column 1, line 4. For "XXXIII 117》, read (XXXII 117».

Page 743, column 2, line 13. For "XXXIV 606», read «XXXIII 606».

\section{VOLUME 36}

Page 753, column-1, line 12. For «XXXI 688», read "XXXI 668».

Page 753, column 1, line 15 from below. For "XXV 296», read "XXXV 296».

Page 756, column 1, line 4. For «a» read "as».

Page 805 , column 2, line 20 from below. For «L.» read «J.».

\section{VOLUME 38}

Page 715, column 1, line 7. For "XXIV 214», read "XXIV 213».

Page 728 , column 1, line 14. For "KLIBanskI», read "KLibansky».

Page 751, column 2, line 26. For "XXXVIII 627», read «XXXVII 627».

\section{VOLUME 40}

Page 730, column 2, line 9. For «Meloor», read «Mellor».

\section{VOLUME 46}

Page 914, column 2, line 6 from below. For "and», read «und».

Page 914, column 2, line 1 from below. For "and», read «und».

\section{VOLUME 48}

Page 1273, column 1, line 9. For "XXXIII 536», read "XXXVIII 536».

Page 1273, column 1, line 6 from below. For "XL 487), read "(XL 487)».

Page 1276, column 1, line 9 from below. For "definablity», read "definability».

Page 1282, column 1, line 25. For "Aussagenkaluküls», read "Aussagenkalküls».

\section{VOLUME 52}

Page 880 , line 24 , and page 881 , line 2 . In sentence (2), replace "or» by «and», with corresponding changes in the analysis on page 881 .

Page 1050, line 12. For "may», read "my». 